http://journal.uinsgd.ac.id/index.php/biodjati

\title{
BACTERIAL CONTAMINATION AT WHITELEG SHRIMP (Litopeanaeus vannamei) IN AQUACULTURE
}

\begin{abstract}
Mashuri Masri $^{1 *}$, Eka Sukmawaty ${ }^{2}$, Fatmawati Nur $^{3}$, Suriani $^{4}$
Received : February 23, 2021

Accepted : May 11, 2021

DOI: 10.15575/biodjati.v6i1.11812

1,2,3 Department of Biology, Faculty of Science and Technology, UIN Alauddin Makassar, Kampus 2, Jl. H.M. Yasin Limpo No. 36, Romangpolong, Gowa 92118, South Sulawesi, Indonesia ${ }^{4}$ Biology Graduate Program, Department of Biology, Faculty of Science and Technology, UIN Alauddin Makassar, Kampus 2, Jl. H.M. Yasin Limpo No. 36, Romangpolong, Gowa 92118, South Sulawesi, Indonesia

e-mail:

*Imashuri.masri@uin-alauddin.ac.id

²ekasukmawaty@uin-alauddin.ac.id

3fate.nurkhalik@uin-alauddin.ac.id

4suryaniscientech@gmail.com

*Corresponding author

Abstract. Indonesia has a very high biodiversity, which has later become one of the natural products of interest to the international community, including fishery products. One of the high-demand Indonesian fishery products is whiteleg shrimp Litopeaneus vannamei. However, safety food Exported whiteleg shrimp products must meet the criteria, including free from bacterial contamination such as Escherichia coli, Salmonella, Vibrio cholera. This study attemptted to analyze E. coli, Salmonella, V. cholerae contamination in 3 ponds in Bojo, Cilellang, and Palanro village in district Malusetasi, Barru Regency, South Sulawesi. Two samplings for each pond were conducted in the morning were pond water and fresh whiteleg shrimp. The E. coli test showed positive in Cilellang village (sample A) with $11 \mathrm{MPN} / \mathrm{g}$, negative in Palanro village (sample B) and in Bojo village (sample C) with the value of $<2 \mathrm{MPN} / \mathrm{g}$. Escherichia coli test showed positive in sample D (Vannamei shrimp in Cilellang village) and sample E (Vannamei shrimp in Palanro village) with 2.0 $M P N / g, 17 \mathrm{MPN} / g$, respectively. Only sample F (Vannamei shrimp in Bojo village) showed a negative result. As for the Salmonella test, positive results showed in sample $A$, while sample $B$ and sample $C$ showed negative results. The Vibrio cholerae test showed negative at all samples. This study concludes that Whiteleg shrimp from ponds in Mallusetasi district is classified as safe for consumption.
\end{abstract}

Keywords: bacterial, contamination, Litopenaus vanname shrimp, pathogenic, Sulawesi

\section{Citation}

Masri, M., Sukmawaty, E., Nur, F. \& Suriani. (2021). Bacterial Contamination at Whitelag Shrimp (Litopeanaeus vannamei) in Aquaculture. Jurnal Biodjati, 6(1), 136-145.

\section{INTRODUCTION}

The demand of abroad consumers for Indonesian fishery products, especially shrimp in fresh and processed conditions increases. Some of Indonesia's shrimp export destinations, such as Japan, America, and Europe, have required strict quality requirements (Pramoda et al., 2017). Globalization of world trade places food security and quality assurance as a prerequisite as the upgrading of production technology, handling and distribution of food, and awareness of the importance of safe and food quality (Panghal et al., 2018).

Microbiological conditions are one of the supporting parameters for the success of seawater (ponds) and freshwater cultivation (Sohel \& Ullah, 2012; Rahman et al., 2013). The group of coli bacteria and pathogenic bacteria are used as indicators of marine 


\section{JURNAL BIDDJATI}

http://journal.uinsgd.ac.id/index.php/biodjati

and terrestrial aquaculture (Sumampouw \& Risjani, 2014; Mathew et al., 2019). The imported shrimp products must be guaranteed the requirement of safe food as follow: (a) free of heavy metals, (b) fresh and free of $\mathrm{H}_{2} \mathrm{~S}$, blackspot, and indole, (c) clean, free of bacterial contaminants (d) free of residue and antibiotics (Mathew et al., 2019).

Water ponds, water processing, and ice used in the production process are among the causes of shrimp contamination to pathogenic bacteria, besides sanitation and hygiene factors (Sohel \& Ullah, 2012). Groups of microorganisms commonly used as indicators of water pollutants and have higher endurance than other pathogenic bacteria, also more easily isolated and grown are groups of coli bacteria (Sumampouw \& Risjani, 2014; Mathew et al., 2019).

Inadequate water quality in shrimp farming activities causes massive seed loss and decline in post-harvest quality, indicated by the presence of pathogenic bacteria with high density (Armenta-Bojórquez et al., 2021). The regulation should take into account, $E$. coli bacteria found in density exceeded the threshold determined by the Ministry of Environment based on Government Regulation SNI $2728-2018$ is $1000 / 100 \mathrm{ml}$ (SNI, 2018). In the event of contamination, the number of E. coli bacteria becomes numerous and exceeds other pathogenic bacteria. These bacteria indicate the presence of pathogens in water other than viruses, protozoa, and parasites (De Brauwere et al., 2014; Mathew et al., 2019). WHO recommends three groups of marine and terrestrial pollution indicator bacteria, namely fecal coliform, fecal streptococcus, and pathogens (Salmonella sp, Vibrio sp, E. coli) (Sutiknowati, 2014).

One of Indonesia's shrimp-producing areas is Mallusetasi district located in Barru Regency, South Sulawesi. One of the shrimp producers for export production. However, there is fear of harvest failure considering the last few years' drastic loss by mass deaths that occurred. Based on information from the farmers in Mallusetasi district, the marine waters of Makassar Strait are polluted by chemicals from the cultivation of pearl shells influencing shrimp aquaculture yield in Mallusetasi district. Other information from community leaders and direct observation in Mallusetasi district indicates that residents or communities of this coastal area do not have a permanent septic tank system, they only make a rectangular chamber for fecal stools in the house of each family. Besides, many people do not have a fixed stover (dispose of any place), and there are even coastal communities that make booths and floorboards by using poles and buffers above seawater so that the stool directly fell into the seawater.

The coastal areas suffer from environmental degradation, which caused a decrease in shrimp cultivation (Rahman et al., 2013). The numerous contamination source encourages researchers to explore it, including this research, which tried to test E. coli, Salmonella, and $V$. cholerae contamination based on SNI 2728-2018, in 3 ponds in Bojo, Cilellang, and Palanro village in district Malusetasi, Barru Regency, South Sulawesi. The ponds in these 3 villages are far from one another but located very close to the coast and residential areas. The 3 ponds also have different $\mathrm{pH}$ and salinity, the Cilellang village pond has a $\mathrm{pH}$ of $7,5-8$, and $25-30 \%$ salinity, the Palanro village pond has a $\mathrm{pH}$ of $7-8$ with a salinity of $20-25 \%$ while the Bojo village pond has a $\mathrm{pH}$ of $7-8$ with a salinity of $30 \%$.

\section{MATERIALS AND METHODS}

Two samples which are fresh whiteleg shrimp and water ponds were taken using 


\section{JURNAL BIDDJATI}

http://journal.uinsgd.ac.id/index.php/biodjati

nets in the morningin each village (Cillellang, Palanro, and Bojo) (Figure 1). All testing methods were carried out based on SNI 27282018 combined with Standard of Procedure in The Makassar Fishery Product Quality Testing and Development Center (Balai Pembinaan dan Pengujian Mutu Hasil Perikanan (BPPMPH)) Makassar.

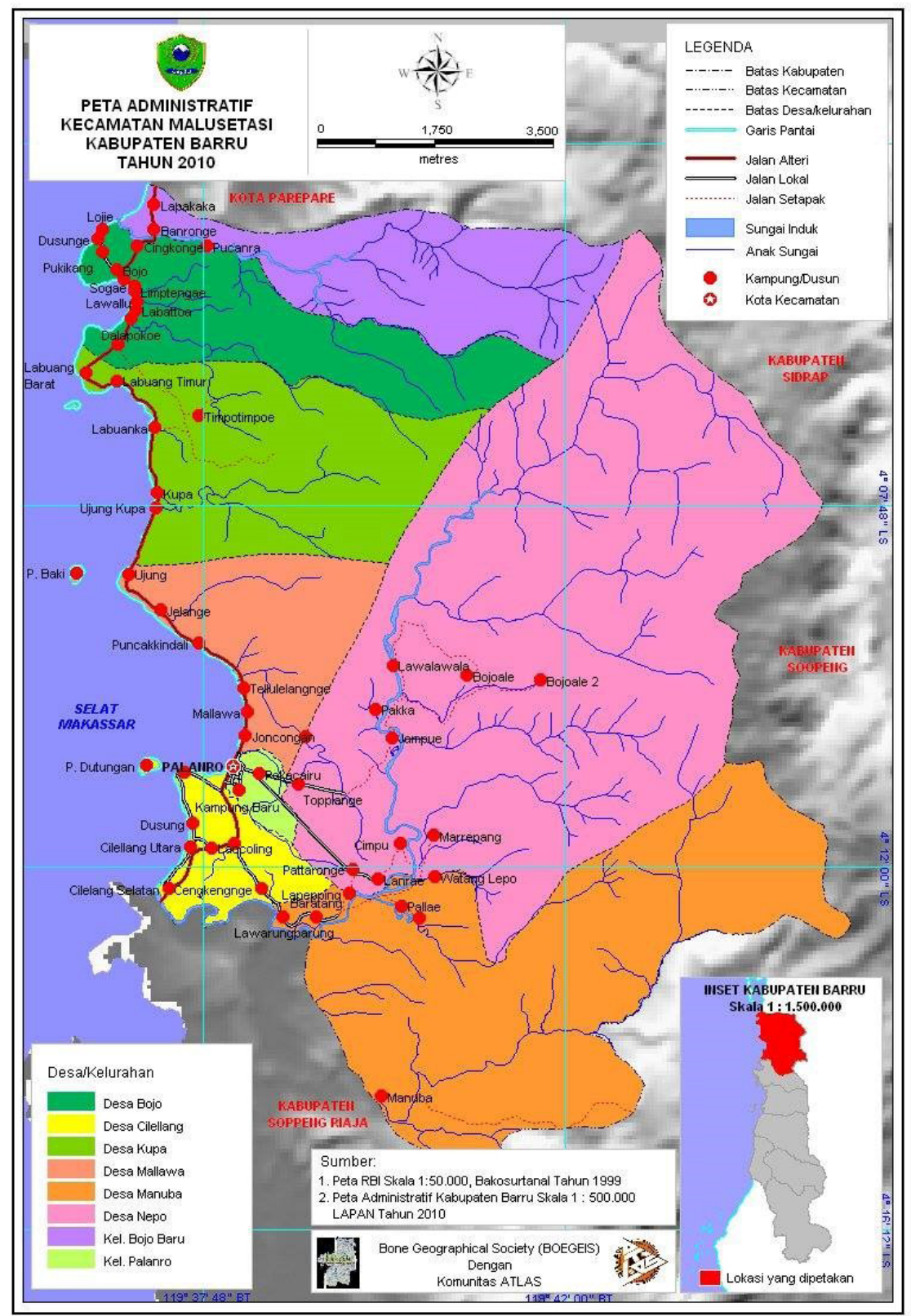

Description:

: Cilellang Village

: Palanro Village

: Bojo Village

Figure 1. Map of the sampling point 


\section{JURNAL BIDDJATI}

http://journal.uinsgd.ac.id/index.php/biodjati

\section{Sample Preparation}

Twenty-five (25) g samples of fresh whiteleg shrimp were prepared from the abdomen and the head of the shrimp, and put in a sterile icebox container. $225 \mathrm{ml}$ of Butterfield's Phosphate Buffered solution were added and homogenized for 2 minutes. This homogenate was a solution with a dilution of $10^{-1}$. The Test was carried out right after collecting samples.

\section{Escherichia coli Test \\ Coliform Estimation Test}

Dilution $10^{-2}$ was prepared by dissolving $1 \mathrm{ml}$ of $10^{-1}$ solution into $9 \mathrm{ml}$ of Butterfield's Phosphate Buffered. $1 \mathrm{ml}$ of dilution of each dilution were then transferred by using a sterile pipette, into 3 series of lauryl tryptose broth (LTB) containing the Durham tube. The tubes were incubated for 48 hours at $35^{\circ} \mathrm{C}$. The gas formed after 24 hours of incubation, and the negative tubes were reincubated for another 24 hours. The positive tube is marked by turbidity and gas in the Durham tube.

\section{Coliform Affirmation Test}

The positive LTB tubes were inoculated to the Brilliant Green Lactose Bile (BGLB) Broth tubes containing the Durham tube using the inoculation loop. The inoculated BGLB Broth tubes were incubated for 48 hours at $35^{\circ} \mathrm{C}$. The BGLB Broth tubes that produce gas for 48 hours at $35^{\circ} \mathrm{C}$ were checked. The positive tube is characterized by turbidity and gas in the tube Durham. The most probable number (MPN) value was determined based on the number of positive BGLB Broth tubes. The value was expressed as "MPN/g coliform".

\section{Escherichia coli Predicted Test}

Each positive LTB tube was inoculated to the E. coli (EC) Broth tubes containing the Durham tube using the inoculation loop. EC Broth tubes were incubated in the water bath for 48 hours at $45^{\circ} \mathrm{C}$. The EC Broth tubes that generate gas for 24 hours were checked. If negative, the tubes were incubated again for up to 48 hours. The positive tube is characterized by turbidity and gas in the Durham tube. Water bath must be clean, water in it must be higher than the liquid's height in the incubated tube. MPN was determined based on the number of positive EC Broth. The value was denoted as "MPN/g fecal coliform".

\section{Escherichia coli Affirmation Test}

Samples from positive EC Broth tubes were inoculated by using a scratching inoculation loop to Levine's Eosin Methylen Blue (LEMB) agar and incubated for 24 hours at $35^{\circ} \mathrm{C}$. The suspected colony of E. coli giving a distinctive feature of black on the middle with or without metallic green. More than one colony of $E$. coli in each LEMB agar plate was then scraped onto Plate Count Agar (PCA) media using the needle planting and incubated for 24 hours at $35^{\circ} \mathrm{C}$.

\section{Morphological Test}

Unspecified (typical) colonies of E. coli were transferred to a tilted PCA medium.

\section{Biochemical Test}

Biochemical Tests include Indole, Methyl Red (MR), Voges Proskauer (VP), Citrate Test, and gas production.

Indole test was carried out to determine the ability of the bacteria to convert tryptophan into indole. Bacterial culture was made by taking 1 loop bacteria from PCA into the tryptone broth and incubating it for 24 hours at $35^{\circ} \mathrm{C}$. The indole test was carried out by adding $0.2 \mathrm{ml}-0.3 \mathrm{ml}$ of Kovacs reagent into the culture, positive result was determined from the solution turns from yellow to cherry red

Voges proskauer test was carried out to determine if an organism produces acetylmethyl carbinol from glucose fermentation. First, bacterial culture was made by inoculating 1 loop of inoculant from PCA into the 


\section{JURNAL BIDDJATI}

http://journal.uinsgd.ac.id/index.php/biodjati

MRVP Broth and incubated for 48 hours at $35^{\circ} \mathrm{C} .1 \mathrm{ml}$ of each growing MRVP Broth was transferred to a sterile $13 \mathrm{~mm} \times 100 \mathrm{~mm}$ test tube, $0.6 \mathrm{ml}$ of alpha naphthol solution and $0.2 \mathrm{ml} \mathrm{40 \%} \mathrm{KOH}$ were then added. The mixture was shaken and added a small amount of creatine crystals to speed up the reaction. the mixture was then let stand for 2 hours. A pink-red color at the surface of the tube was considered to be a positive result. Methyl red test was carried out to detects the production of acid by bacteria during the fermentation of glucose. the MRVP Broth above was reincubated for 48 hours at $35^{\circ} \mathrm{C}$ and 5 drops of Methyl red indicator were added to the MRVP Broth. A positive result was shown by a change in the color of the methyl red indicator from yellow to red. Citrate test was carried out to differentiate among the Gram-Negative Scratched 1 loop of PCA slanted onto the surface of simmon's citrate agar. Incubated for 96 hours at $35^{\circ} \mathrm{C}$. Positive result showed by a color change from green to blue along the slant of media. Gas production in selective lactose media was also carried out. Bacterial culture was inoculated into LTB, and was incubated for 48 hours at $35^{\circ} \mathrm{C}$ (Standard of Procedure, 2018).

\section{Salmonella Test}

\section{Isolation of Salmonella}

The samples which previously inoculated Tetrathionate Broth (TTB) were incubated into Hectoen Enteric (HE), Xylose Lysine Desoxycholate (XLD), and Bismuth sulfite Agar (BSA) media for 24 hours at $35^{\circ} \mathrm{C}$.

\section{The Urease Tests}

The urease test was carried out to determine the ability of an organism to split urea. 1 ose culture from each positive Triple Sugar Iron (TSI) presumptive test was moved into Rapid Urea Broth and incubated for 2 hours in the water bath at $37^{\circ} \mathrm{C}$.

\section{Urease Negative Culture Test LDB (Lysine Decarboxylase Broth)}

One loop from TSI were transferred into LDB medium. The lid was loosened and incubated for 48 hours at $35^{\circ} \mathrm{C}$, but it was observed after 24 hours. Salmonella gives an alkaline reaction characterized by a purple color on all media.

\section{Phenol Red Dulcitol or Purple Broth Base with $0.5 \%$ Dulcitol}

One loop from TSI was moved into dulcitol Broth medium. The lid was loosened and incubated for 48 hours at $35^{\circ} \mathrm{C}$, but it was observed 24 hours. Salmonella gives positive results, characterized by gas formation in the Durham tube and acid pH (yellow) on media.

\section{Polyvalent Somatic (O) Serological Test}

One loop culture of TSI was taken that has been incubated for 24-48 hours, and it was placed on top of the preparatory glass, then $0.85 \%$ saline solution sterile was dropped and emulsified. 1 drop Salmonella Polyvalent Somatic (O) Antiserum was laid in addition to colony suspension. Colonies of Antiserum were Mixed gradually with colony suspension until well blended. The control was conducted using saline and Antiserum solution. The mixture was tilted to the left and right, and it was observed immediately on the dark background rear.

\section{Additional Biochemical Tests}

The additional biochemical Tests were: Phenol red lactose or purple Lactose Broth test, Phenol red sucrose or purple sucrose Broth test, Methyl Red - Voges-Proskauer (MR - VP) Broth test, and Simmons citrate Agar (Standard of Procedure, 2018).

\section{Vibrio cholerae Test Isolation of Vibrio cholerae Test}

Without shaking the tube, 1 loop culture of each positive tube was taken at each dilution as much as $1 \mathrm{~cm}$ from the liquid surface, 


\section{JURNAL BIDDJATI}

http://journal.uinsgd.ac.id/index.php/biodjati

and it was then scratched into the Thiosulfate-Citrate-BileSalts-Sucrose (TCBS) agar. TCBS agar was incubated at $36^{\circ} \mathrm{C}$ for $18-24$ hours. The presence of $V$. cholerae on TCBS agar was observed. Colonies of $V$. cholerae are large, smooth surface, somewhat flat, the center is opaque, and the edges are bright, yellow (positive sucrose).

\section{Purification}

Three unexpected colonies or more were taken from each TCBS agar, and were incubated into T1N1 agar or TSA $+1.5 \%$ $\mathrm{NaCl}$ (total containing $2 \% \mathrm{NaCl}$ ) for $18-24$ hours at $36^{\circ} \mathrm{C} \pm 1^{\circ} \mathrm{C}$.

\section{Preliminary Biochemical Test}

Preliminary biochemical tests include oxidase test, sensitivity to $0 / 129$ vibriostat Test, TSI Agar and Kligger Iron Agar (KIA), ortho-nitrophenol test for beta-galactosidase production (ONPG) test, Oxidative fermentative test, and Gram staining.

\section{Advance Biochemical Test}

Advance biochemical Tests include urea hydrolysis, Arginine dihydrolase test, Lysine decarboxylase test, ornithine decarboxylase Test, salt-tolerant test, growth on $42^{\circ} \mathrm{C}$ Test, VP test, carbohydrate fermentation tests, serology test (Standard, 2018).

\section{RESULTS AND DISCUSSION}

Based on SNI 2728-2018 (SNI, 2018) about food quality and safety requirements for fresh shrimp, the presence of E. coli in fresh shrimp must be less than $2 \mathrm{MPN} / \mathrm{g}$, while the presence of Salmonella and Vibrio cholerae must be negative/25 g. The result of pathogenic bacteria in pond water presented in Table 1.

Table 1. Pathogenic bacteria in pond water

\begin{tabular}{ccccc}
\hline \multirow{2}{*}{ Test } & Unit & \multicolumn{3}{c}{ Sample } \\
\cline { 3 - 5 } & & $\mathrm{A}$ & $\mathrm{B}$ & $\mathrm{C}$ \\
\hline E. coli & $\mathrm{MPN} / \mathrm{g}$ & $11^{*}$ & $<2^{* *}$ & $<2 * *$ \\
Salmonella & Per $25 \mathrm{~g}$ & Positive & Negative & Negative \\
V. cholerae & Per $25 \mathrm{~g}$ & Negative & Negative & Negative \\
SPC & Kol $/ 25 \mathrm{~g}$ & $1.6 \times 10^{4}$ & $1.6 \times 10^{5}$ & TNTC \\
\hline
\end{tabular}

Description:

$\begin{array}{ll}\mathrm{A} & : \text { water pond of Cilellang village } \\ \mathrm{B} & : \text { water pond of Palanro village } \\ \mathrm{C} & : \text { water pond of Bojo village } \\ * & : \text { Positive } \\ * * & : \text { Negative } \\ \text { TNTC } & : \text { too numerous to count }\end{array}$

The analysis of some pond water samples in several villages in district Malusetasi, Barru Regency, South Sulawesi showed positive results that exceeded the maximum standard (table 1). Contaminated pond water is caused by the distance of ponds with adjacent residents' settlement, while some people lack awareness of environmental hygiene.
The results of the analysis of E. coli parameter test with a maximum threshold of microbial contamination on fresh shrimp based on SNI 2728-2018 (SNI, 2018), i.e., $<2 \mathrm{MPN} / \mathrm{g}$, it can be seen that sample B (pond water of Palanro), sample $\mathrm{C}$ (pond water Bojo village), and sample F (shrimp Vannamei from Bojo village) have the same result of $<2 \mathrm{MPN}$ 


\section{JURNAL BIDDJATI}

http://journal.uinsgd.ac.id/index.php/biodjati

/ g shows the negative result of E. coli. While sample A (water pond Cilellang village), sample D (shrimp Vannamei from Cilellang village), and sample E (shrimp Vannamei from
Palanro village) gave a result of $11 \mathrm{MPN} / \mathrm{g}$, 2.0 MPN / g, and 17 MPN / g, respectively, meaning the samples are positive of E. coli (Table $1 \& 2$ ).

Table 2. Pathogenic bacteria on shrimp

\begin{tabular}{ccccc}
\hline \multirow{2}{*}{ Test } & Unit & \multicolumn{3}{c}{ Sample } \\
\cline { 3 - 5 } & & $\mathrm{D}$ & $\mathrm{E}$ & $\mathrm{F}$ \\
\hline E. coli & $\mathrm{MPN} / \mathrm{g}$ & $2,0^{*}$ & $17^{* *}$ & $<2 * *$ \\
Salmonella & Per 25 gr & Negative & Negative & Negative \\
V. cholerae & Per 25 gr & Negative & Negative & Negative \\
SPC & $\mathrm{Kol} / 25 \mathrm{gr}$ & - & - & - \\
\hline
\end{tabular}

\begin{tabular}{ll}
\hline Description: \\
$\mathrm{D}$ & : Vannamei Shrimp of Cilellang village \\
$\mathrm{E}$ & $:$ Vannamei Shrimp of Palanro village \\
$\mathrm{F}$ & $:$ Vannamei Shrimp of Bojo village \\
$*$ & $:$ Positive \\
$* *$ & : Negative
\end{tabular}

These results show the discontinuity especially between sample B and sample E, in which samples of shrimp contaminated with $E$. coli while the water sample negative E. coli. The possibility of these results because shrimp are contaminated with $E$. coli from pond sediment. E. coli bacteria can also come from mud or pond bottom sediment. According to Stocker et al. (2018) and Martin-Diaz et al. (2020), sedimentary particles from pond bottom attached to shrimp pleopods can be a source of coliform and $E$. coli contamination, while the discovery of $E$. coli in the water is possible because the pond water is sourced from seawater polluted by household wastes such as human feces and foodstuffs from the residential community (Stocker et al., 2018; Martín-Díaz et al., 2020). Chemical compounds, microorganisms, and hazardous physical contamination found in fishery products, caused by the environment where fish live, including the location of cultivation (Mathew et al., 2019). The ponds in these 3 villages are distant from one another but are found exceptionally near to the coast and residential areas. Residents of this coastJurnal Biodjati 6(1):136-145, May 2021 al zone do not have a permanent septic tank framework, and as a replacement, hey make a rectangular chamber with a hole in the bottom for fecal stools in the house of each family, the stool directly fell within the seawater.

From the analysis results, only sample A (water pond Cilellang village) showed positive results of Salmonella (Table 1) because it exceeds the maximum threshold of microbial contamination on fresh shrimp based on SNI 2728-2018 (SNI, 2018), i.e., negative/25 g. However, the test result in sample D (shrimp Cilellang village) shows this negative result because Salmonella bacteria do not contaminate shrimp sampling in the pond water (Table 2).

Salmonella contamination on shrimp causes the decrease of shrimp quality organoleptically, so consumers do not accept it. To reduce Salmonella contamination, Salmonella exposure should be decreased, which generally done by the use of antibiotics and synthetic preservatives by farmers and the shrimp processing industry (Done et al., 2015; Nair et al., 2018). Use of antibiotics in shrimp during cultivation and processing is prohibited by 


\section{JURNAL BIDDJATI}

http://journal.uinsgd.ac.id/index.php/biodjati

Indonesia and export destination countries, thus detectable antibiotic components in shrimp export will be rejected (Thornber et al., 2020). The use of antibiotics at inappropriate doses, causing antibiotic resistance (Haddadin et al., 2019; Thornber et al., 2020), may also negatively affect food products consumed, reactivate sensitivity, or physiological disorders in humans (Lulijwa et al., 2020).

E. coli and Salmonella bacteria usually originate in animals and humans. If these types of bacteria are found in the waters, this indicates pollution occurs in thewaters, so this bacteria can be used as an indicator of contamination (Frick et al., 2020; Wen et al., 2020). Cho et al. (2020) and Wen et al. (2020) stated E. coli and Salmonella are the indicator organisms of fecal contamination that are not derived from the aquatic environment (Cho et al., 2020; Wen et al., 2020).

According to Devane et al. (2020), E. coli and Salmonella are microorganisms indicating the occurrence of pollution that is not Indigenous in the aquatic environment (Devane et al., 2020). Besides, E. coli and Salmonella contamination in shrimp can become indications of low sanitation and hygiene conditions, this is supported by Hamilton et al. (2018), which says that the presence of harmful bacteria in food is an indicator of poor sanitation on handling and processing (Hamilton et al., 2018), and the contamination may originate from humans and pets (Cho et al., 2020).

From the result of the analysis on the shrimp sample of $V$. cholerae parameter test, it revealed that all samples showed the negative result of $V$. cholerae based on SNI 2728-2018 (SNI, 2018) (Table 2). The lack of pathogenic bacteria found in shrimp in ponds due to the treatment of probiotics in shrimp (Mathew et al., 2019). Following Knipe et al. (2021), the addition of probiotic bacteria to shrimp main- tenance containers can serve as complementary sources of feed or contribution to the digestive system food and suppress the population of pathogenic bacteria (Knipe et al., 2021). Fish Farmers from 3 villages were used probiotic treatment in their ponds.

Transmission sources for Vibrio come from Food derived from fisheries, as one of the most common transmission sources (Mutiara et al., 2019; Helmi et al., 2020). Water with a high salt substance such as seawater may be a common living place of Vibrio sp that cause defilement (Mutiara et al., 2019), apart from some other factors such as temperature, hygiene, and concentration of Food that also affects the transmission (Baker-Austin et al., 2018). Taken together, it can be concluded that the whiteleg shrimp within the ponds in Mallusetasi district, Barru Regency, South Sulawesi considered secure for utilization based on SNI 2728-2018 with E. coli, Salmonella, and $V$. cholerae test.

\section{ACKNOWLEDGEMENTS}

The authors would like to thank The Makassar Fishery Product Quality Testing and Development Center (Balai Pembinaan dan Pengujian Mutu Hasil Perikanan (BPPMPH)) Makassar for collaboration in this research.

\section{REFERENCES}

Armenta-Bojórquez, A. D., Valenzuela-Castañeda, A. R., Fitzsimmons, K., López-Alvarez, E. S., RodríguezQuiroz, G. \& Valenzuela-Quiñónez, W. (2021). Pacific White Shrimp and Tomato Production using Water Effluents and Salinity-tolerant Grafted Plants in an Integrated Aquaponic Production system. Journal of Cleaner Production, 278(1), 1-12. 


\section{JURNAL BIDDJATI}

http://journal.uinsgd.ac.id/index.php/biodjati

Baker-Austin, C., Oliver, J. D., Alam, M., Ali, A., Waldor, M. K., Qadri, F. \& MartinezUrtaza, J. (2018). Vibrio spp. Infections. Nature Reviews Disease Primers, 4(1), 1-19.

Cho, S., Jackson, C. R. \& Frye, J. G. (2020). The Prevalence and Antimicrobial Resistance Phenotypes of Salmonella, Escherichia coli and Enterococcus sp. in Surface Water. Letters in Applied Microbiology, 71(1), 3-25.

De Brauwere, A., Ouattara, N. K. \& Servais, P. (2014). Modeling Fecal Indicator Bacteria Concentrations in Natural Surface Waters: A Review. Critical Reviews in Environmental Science and Technology, 44(21), 2380-2453.

Devane, M. L., Moriarty, E., Weaver, L., Cookson, A. \& Gilpin, B. (2020). Fecal Indicator Bacteria from Environmental Sources; Strategies for Identification to Improve Water Quality Monitoring. Water Research, 185, 1-23.

Done, H. Y., Venkatesan, A. K. \& Halden, R. U. (2015). Does the Recent Growth of Aquaculture Create Antibiotic Resistance Threats Different from those Associated with Land Animal Production in Agriculture?. AAPS Journal, 17(3), 513-524.

Frick, C., Vierheilig, J., Nadiotis-Tsaka, T., Ixenmaier, S., Linke, R., Reischer, G. H., Komma, J., Kirschner, A. K. T., Mach, R. L., Savio, D., Seidl, D., Blaschke, A. P., Sommer, R., Derx, J. \& Farnleitner, A. H. (2020). Elucidating Fecal Pollution Patterns in Alluvial Water Resources by Linking Standard Fecal Indicator Bacteria to River Connectivity and Genetic Microbial Source Tracking. Water Research, 184(20), 1-40.

Haddadin, R. N., Alsous, M., Wazaify, M. \& Tahaineh, L. (2019). Evaluation of
Antibiotic Dispensing Practice in Community Pharmacies in Jordan: A Cross Sectional Study. PLoS ONE, 14(4), $1-15$.

Hamilton, K. A., Chen, A., de-Graft Johnson, E., Gitter, A., Kozak, S., Niquice, C., Zimmer-Faust, A. G., Weir, M. H., Mitchell, J. \& Gurian, P. L. (2018). Salmonella Risks Due to Consumption of Aquaculture-produced Shrimp. Microbial Risk Analysis, 9(17), 22-32.

Helmi, A. M., Mukti, A. T., Soegianto, A. \& Effendi, M. H. (2020). A Review of Vibriosis in Fisheries: Public Health Importance. Systematic Reviews in Pharmacy, 11(8), 51-58.

Knipe, H., Temperton, B., Lange, A., Bass, D. \& Tyler, C. R. (2021). Probiotics and Competitive Exclusion of Pathogens in Shrimp Aquaculture. Reviews in Aquaculture, 13(1), 324-352.

Lulijwa, R., Rupia, E. J. \& Alfaro, A. C. (2020). Antibiotic Use in Aquaculture, Policies and Regulation, Health and Environmental Risks: A Review of the Top 15 Major producers. Reviews in Aquaculture, 12(2), 640-663.

Martín-Díaz, J., Lucena, F., Blanch, A. R. \& Jofre, J. (2020). Review: Indicator Bacteriophages in Sludge, Biosolids, Sediments and Soils. Environmental Research, 182:109133, 1-7.

Mathew, S., Raman, M., Parameswaran, M. K. \& Rajan, D. P. (2019). Fish and fishery products analysis: A theoretical and practical perspective. In Fish and Fishery Products Analysis: A Theoretical and Practical Perspective. Singapore: Springer Nature Pte Ltd.

Mutiara, A., Azhari, R., Apriliani, I. M. \& Syarifuddin, M. (2019). Vibrio cholerae Test on Fishery Products at Cirebon Test and Application of Fishery Pro-ducts 


\section{JURNAL BIDDJATI}

http://journal.uinsgd.ac.id/index.php/biodjati

Technical Unit Agency, West Java, Indonesia. World Scientific News, 119, 192-203.

Nair, D. V. T., Venkitanarayanan, K. \& Johny, A. K. (2018). Antibiotic-resistant Salmonella in the Food Supply and the Potential Role of Antibiotic Alternatives for Control. Foods, 7(10), 1-24.

Panghal, A., Chhikara, N., Sindhu, N. \& Jaglan, S. (2018). Role of Food Safety Management Systems in Safe Food Production: A Review. Journal of Food Safety, 38(4), 1-11.

Pramoda, Radityo dan Maharani Putri, H. (2017). Penerapan Sertifikasi Aquaculture Stewardship Council(Asc) Terhadap Produk Udang Budidaya (Studi Kasus: Tarakan - Kalimantan Utara). Jurnal Borneo Administrator, 13(2), 89-109.

Rahman, M. M., Giedraitis, V. R., Lieberman, L. S., Akhtar, M. T. \& Taminskienè, V. (2013). Shrimp Cultivation with Water Salinity in Bangladesh: The Implications of an Ecological Model. Universal Journal of Public Health, 1(3), 131142.

Standar Nasional Indonesia (SNI). (2018). Indonesia 01-2728.3-2006 Udang segar - Bagian 3 Penanganan dan pengolahan. 2018-2020. Retrieved from http://sispk. bsn.go.id/SNI/DetailSNI/12069.

Standard of Procedure. (2018). The Makassar Fishery Product Quality Testing and Development Center (Balai Pembinaan dan Pengujian Mutu Hasil Perikanan (BPPMPH)) Makassar.
Sohel, M. S. I. \& Ullah, M. H. (2012). Ecohydrology: A Framework for Overcoming the Environmental Impacts of Shrimp Aquaculture on the Coastal Zone of Bangladesh. Ocean and Coastal Management, 63, 67-78.

Stocker, M. D., Penrose, M. \& Pachepsky, Y. A. (2018). Spatial Patterns of Escherichia coli Concentrations in Sediment Before and After High-Flow Events in a First-Order Creek . Journal of Environmental Quality, 47(5), 958966.

Sumampouw, O. J. \& Risjani, Y. (2014). Bacteria as Indicators of Environmental Pollution: Review. International Journal of Ecosystem, 4(6), 251-258.

Sutiknowati, L. I. (2014). Mikrobiologi Seawater Quality For Shrimp Mariculture Based On Microbiology Parameters. Jurnal Ilmu Dan Teknologi Kelautan Tropis, 6(1), 157-170.

Thornber, K., Verner-Jeffreys, D., Hinchliffe, S., Rahman, M. M., Bass, D. \& Tyler, C. R. (2020). Evaluating antimicrobial resistance in the global shrimp industry. Reviews in Aquaculture, 12(2), 966986.

Wen, X., Chen, F., Lin, Y., Zhu, H., Yuan, F., Kuang, D., Jia, Z. \& Yuan, Z. (2020). Microbial indicators and their use for monitoring drinkingwater quality - A Review. Sustainability, 12(6), 1-14. 